\title{
The queen is dead-long live the workers: intraspecific parasitism by workers in the stingless bee Melipona scutellaris
}

\author{
D. A. ALVES, ${ }^{*}$ V. L. IMPERATRIZ-FONSECA, ${ }^{*}$ T. M. FRANCOY,+ P. S. SANTOS-FILHO, ${ }^{*}$ \\ P. NOGUEIRA-NETO ${ }^{*}$ J. BILLEN $\ddagger$ and T. WENSELEERS \\ *Bee Laboratory, Bioscience Institute, University of São Paulo, Rua do Matão Trav. 14, 321, 05508-900 Sao Paulo, Brazil, \\ †School of Arts, Sciences and Humanities, University of São Paulo, Rua Arlindo Béttio 1000, 03828-000 Sao Paulo, Brazil, \\ $\ddagger$ Laboratory of Entomology, Zoological Institute, Catholic University of Leuven, Naamsestraat 59, B-3000 Leuven, Belgium
}

\begin{abstract}
Insect societies are well known for their high degree of cooperation, but their colonies can potentially be exploited by reproductive workers who lay unfertilized, male eggs, rather than work for the good of the colony. Recently, it has also been discovered that workers in bumblebees and Asian honeybees can succeed in entering and parasitizing unrelated colonies to produce their own male offspring. The aim of this study was to investigate whether such intraspecific worker parasitism might also occur in stingless bees, another group of highly social bees. Based on a large-scale genetic study of the species Melipona scutellaris, and the genotyping of nearly 600 males from 45 colonies, we show that $\sim 20 \%$ of all males are workers' sons, but that around $80 \%$ of these had genotypes that were incompatible with them being the sons of workers of the resident queen. By tracking colonies over multiple generations, we show that these males were not produced by drifted workers, but rather by workers that were the offspring of a previous, superseded queen. This means that uniquely, workers reproductively parasitize the next-generation workforce. Our results are surprising given that most colonies were sampled many months after the previous queen had died and that workers normally only have a life expectancy of $\sim 30$ days. It also implies that reproductive workers greatly outlive all other workers. We explain our results in the context of kin selection theory, and the fact that it pays workers more from exploiting the colony if costs are carried by less related individuals.
\end{abstract}

Keywords: Meliponini, reproductive conflict, social insects, social parasitism, stingless bees, worker reproduction

Received 29 April 2009; revision received 1 July 2009; accepted 14 July 2009

\section{Introduction}

Social insects such as ants, bees and wasps are well known for their high degree of cooperation, but the nonclonal structure of their colonies also sets the stage for various reproductive conflicts (Hamilton 1964; Trivers \& Hare 1976; Ratnieks \& Reeve 1992; Beekman \&

Correspondence: Denise Alves, Fax: +55 11 30917533;

E-mail: daalves@ib.usp.br
Ratnieks 2003; Ratnieks et al. 2006). One such conflict is queen-worker conflict over male parentage (Trivers \& Hare 1976; Bourke 1988; Hammond \& Keller 2004; Ratnieks et al. 2006; Wenseleers \& Ratnieks 2006a). Workers, although generally being unable to mate, are usually capable of laying unfertilized eggs, which develop into male offspring if successfully reared. In addition, they are generally selected to do so, as workers are always most related to their own sons $(r=0.5)$ (Hamilton 1964; Trivers \& Hare 1976; Cole 1986; Bourke 
1988; Wenseleers et al. 2004b). Hence, a queen-worker conflict over the production of males ensues. Several factors, however, may help to resolve queen-worker conflict over male parentage and keep successful worker reproduction at a low level (Beekman \& Ratnieks 2003; Hammond \& Keller 2004; Ratnieks et al. 2006; Wenseleers \& Ratnieks 2006a). First, the queen herself can counter worker reproduction by selectively eating any worker-laid eggs ('queen policing') (Oster \& Wilson 1978; Ratnieks \& Reeve 1992; Wenseleers et al. 2005a, b; reviewed in Ratnieks et al. 2006; Wenseleers \& Ratnieks 2006a). Second, the workers may also cannibalize eggs laid by other workers ('worker policing', Ratnieks 1988; Ratnieks \& Visscher 1989). This behaviour is seen particularly in species with multiple mated queens (such as honeybees, where worker policing was first discovered), due to the fact that the workers are more related to the queen's sons (brothers, $r=0.25$ ) than to the sons of other workers in that situation (a mix of full- and half-nephews, $r<0.25$ ) (Ratnieks 1988; Ratnieks et al. 2006; Wenseleers \& Ratnieks 2006a, b; Ratnieks \& Wenseleers 2008). By contrast, in species with a single-mated queen (such as some ants, bumblebees and stingless bees), workers are on average more related to the sons of other workers (full-nephews, $r=0.375)$, than to the sons of the queen $(r=0.25)$, and so collectively favour worker reproduction. Nevertheless, even in these species, worker reproduction may not always reach high levels, probably because of colony-level costs associated with worker reproduction, caused by the fact that reproductive workers in some species carry out less work in the colony (Cole 1986; Bourke 1988; Hillesheim et al. 1989; Wenseleers et al. $2004 b$ ) or because worker male production is traded off against worker production, thereby reducing future colony productivity (Ratnieks \& Reeve 1992; Tóth et al. 2004; Wenseleers \& Ratnieks 2006a; Ohtsuki \& Tsuji 2009).

Recently, it has also been discovered that workers may not only exploit their own colony by laying male eggs, but that they may also parasitize and reproduce in other, unrelated colonies away from their natal nest (Beekman \& Oldroyd 2008). For example, in the common bumblebee Bombus terrestris, workers may succeed in entering unrelated colonies, where they appear to reproduce earlier than normal, thereby insuring that their sons have a greater mating success than if they had produced such males during the normal male production period in their natal colony (Lopez-Vaamonde et al. 2004; Beekman \& Oldroyd 2008). In addition, in two Asian honeybee species, Apis florea (Nanork et al. 2005) and A. cerana (Nanork et al. 2007), it has been shown that particularly queenless nests are prone to be parasitized by non-natal workers. The original interpretation was that this was because of workers from queenright colonies invading these nests, and that it represented a strategy to evade policing in their natal nest, as worker policing is generally switched off in queenless nests (Nanork et al. 2005, 2007; Beekman \& Oldroyd 2008). More recent data, however, rather seem to suggest that the majority of the worker parasites appear to come from other queenless hives nearby (Chapman et al. 2009). In both bumblebees and Asian honeybees, non-natal workers also tend to reproduce more than natal ones, presumably because any concomitant costs of worker reproduction are carried by the unrelated workforce of the parasitized nest, thus limiting any inclusive fitness costs (Beekman \& Oldroyd 2008).

The aim of this study was to test whether intraspecific worker parasitism might also occur in stingless bees, another major group of eusocial bees, using the Brazilian species Melipona scutellaris as a model. Like honeybees, stingless bees form perennial, swarmfounded colonies; although more similar to bumblebees, their colonies are headed by a single once-mated queen (Peters et al. 1999). Furthermore, in both wild colonies and colonies kept in apiaries, genetic studies have demonstrated the occasional occurrence of workers that could not be attributed to the current queen, which indicates the presence of either unrelated drifters or workers derived from a superseded queen (Paxton et al. 1999a, 2003; Peters et al. 1999; Palmer et al. 2002). As yet, however, it has not been determined whether such workers might also successfully reproduce, and if so, whether they might do more so than the rest of the colony. In general, worker reproduction in stingless bees, although favoured on relatedness grounds (Tóth et al. $2002 b, 2004)$, can vary from low to high, with anywhere between $0 \%$ and $95 \%$ of the males being workers' sons depending on the species (see e.g. Contel \& Kerr 1976; Sommeijer et al. 1999; Drumond et al. 2000; Palmer et al. 2002; Tóth et al. 2002a, b, 2003; Paxton et al. 2003; Koedam et al. 2005; Gloag et al. 2007; reviewed in Hammond \& Keller 2004; Tóth et al. 2004; Velthuis et al. 2005; Wenseleers \& Ratnieks 2006a). Although the cause of this variation remains unknown, it could perhaps be because of interspecific differences in the colony-level cost of worker reproduction or due to the queen suppressing worker reproduction to varying extents (Tóth et al. 2004; Wenseleers \& Ratnieks 2006a; Ratnieks \& Wenseleers 2008).

Given the occurrence of worker reproduction in stingless bees (Hammond \& Keller 2004; Tóth et al. 2004; Velthuis et al. 2005; Wenseleers \& Ratnieks 2006a) and the documented presence of less related or unrelated worker matrilines within colonies (Paxton et al. 1999a, 2003; Peters et al. 1999; Palmer et al. 2002), the specific 
aims of this study were to test whether in Melipona scutellaris such workers might be able to successfully reproduce, and if so, to what extent. By genotyping colony samples before and after queen supersedure events, we also test for the first time if workers from a superseded queen could keep on producing male offspring, and if so, for how long. This allows us to determine whether workers might have the capacity to reproductively parasitize the next-generation workforce.

\section{Materials and methods}

\section{Study species}

Melipona scutellaris nests in cavities of tree trunks in the Atlantic rainforest and is widely distributed in the Northeast of Brazil (Camargo \& Pedro 2007), where it is commonly kept by regional and traditional beekeepers for honey, pollen and wax (Cortopassi-Laurino et al. 2006). In addition, M. scutellaris is increasingly used for the pollination of various tropical crops (Heard 1999; Castro 2002). Colonies are perennial and swarmfounded, typically contain around 1500 workers and are headed by one single-mated queen (Tóth et al. 2002b). Workers, gynes and males are reared individually in similar-sized cells which are filled with larval food and sealed by workers immediately after an egg is laid. For this study, we used colonies of M. scutellaris maintained in free-foraging wooden nest boxes at Granja São Saruê (Igarassu, Pernambuco state, 750'3.74'S, $\left.34^{\circ} 54^{\prime} 22.87^{\prime \prime} \mathrm{W}\right)$, in the Bee Laboratory at the University

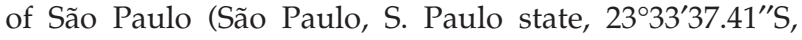
$46^{\circ} 43^{\prime} 53.04^{\prime \prime} \mathrm{W}$ ) and at the Aretuzina Farm (São Simão, S. Paulo state, $\left.21^{\circ} 26^{\prime} 25.97^{\prime \prime} \mathrm{S}, 47^{\circ} 34^{\prime} 54.65^{\prime \prime} \mathrm{W}\right)$. Colonies were spaced $\sim 1-10 \mathrm{~m}$ apart, as is typical in most apiaries and also not uncommon in nature, where several nests can sometimes be found within a few metres of each other, either in the same tree or in different trees (Alves et al. 2005). During the time of our study, colonies were managed only by occasionally providing them with food.

\section{Brood sampling}

Between January 2006 and October 2008, we sampled brood for genetic analysis from a total of 16, 9 and 12 colonies in Igarassu, S. Paulo and S. Simão respectively (Table 1). This was carried out by collecting brood combs containing mature pupae and removing the cell cappings, after which 10 workers and any males present were preserved in absolute ethanol. The remainder of the brood was reintroduced into the natal nest. Brood samples that did not contain male brood were not retained for this study. In S. Paulo and S. Simão, we also repeated the sampling of brood when the mother queen, which was individually marked, was found to be replaced by a new one (Table 1). Such samplings were made at a median number of 206 days after the previous queen had died (range 77-737 days). Overall, we could collect male and worker brood produced by 45 distinct queens (Table 1).

\section{Genetic analysis}

For parentage analysis, we genotyped 10 worker pupae and an average of 13 haploid male pupae (range 5-36, total 576) for each of our 45 colonies (Table 1) at three microsatellite loci, T4-171 (Paxton et al. 1999b), Mbi-254 and Mbi-201 (Peters et al. 1998). These loci were found to be most variable in this species in a preliminary screening of 10 loci. To facilitate parentage reconstruction and wherever necessary, we also noninvasively genotyped the mother queen from a wing tip sample (cf. Châline et al. 2004; Table 1). DNA was extracted using the Chelex method, whereby a single leg (for worker or male pupae) or wing tip sample (from mother queens) was frozen in liquid nitrogen and ground up using a plastic pestle, followed by an incubation at $95{ }^{\circ} \mathrm{C}$ for $15 \mathrm{~min}$ in $200 \mu \mathrm{L}(50 \mu \mathrm{L}$ for wing tip samples) of a $10 \%$ Biorad Chelex 100 resin solution. Samples were vortexed and centrifuged before use. Multiplex PCR reactions were carried out in a $10 \mu \mathrm{L}$ reaction volume, and contained $0.5 \mu \mathrm{M}$ of the forward and reverse primers of each locus, $0.2 \mathrm{~mm}$ of each dNTP, $1.5 \mathrm{~mm} \mathrm{MgCl}_{2}, 1 \mu \mathrm{L}$ of crude DNA extract, 0.4 units of Silverstar Taq polymerase (Eurogentec) and enzyme buffer supplied by the manufacturer. PCR was performed following a touch-down programme (Bonckaert et al. 2008), with an initial denaturation for $3 \mathrm{~min}$ at $94{ }^{\circ} \mathrm{C}$, followed by 20 cycles consisting of $30 \mathrm{~s}$ at $94{ }^{\circ} \mathrm{C}, 30 \mathrm{~s}$ at $58{ }^{\circ} \mathrm{C}$, but decreasing $0.5^{\circ} \mathrm{C}$ in each step and $45 \mathrm{~s}$ at $72{ }^{\circ} \mathrm{C} ; 10$ cycles consisting of $30 \mathrm{~s}$ at $94{ }^{\circ} \mathrm{C}$, $30 \mathrm{~s}$ at $46{ }^{\circ} \mathrm{C}$ and $45 \mathrm{~s}$ at $72{ }^{\circ} \mathrm{C}$; and a final 10 -min extension step at $72{ }^{\circ} \mathrm{C}$. After amplification, $1 \mu \mathrm{L}$ of the PCR product was mixed with $8.8 \mu \mathrm{L}$ formamide and $0.2 \mu \mathrm{L}$ Genescan 500 LIZ size standard (Applied Biosystems), denatured, and loaded onto an ABI-3130 Avant capillary sequencer. Alleles were called using the supplied GeneMapper software and checked by eye. Male genotypes that appeared to suggest they were the sons of drifted workers or sons of workers derived from a superseded queen (see below) were rePCRed, rescored and rechecked twice to eliminate the possibility of genotyping errors.

\section{Analysis of male parentage}

To infer male parentage, we first reconstructed the genotype of each mother queen and that of her mate 


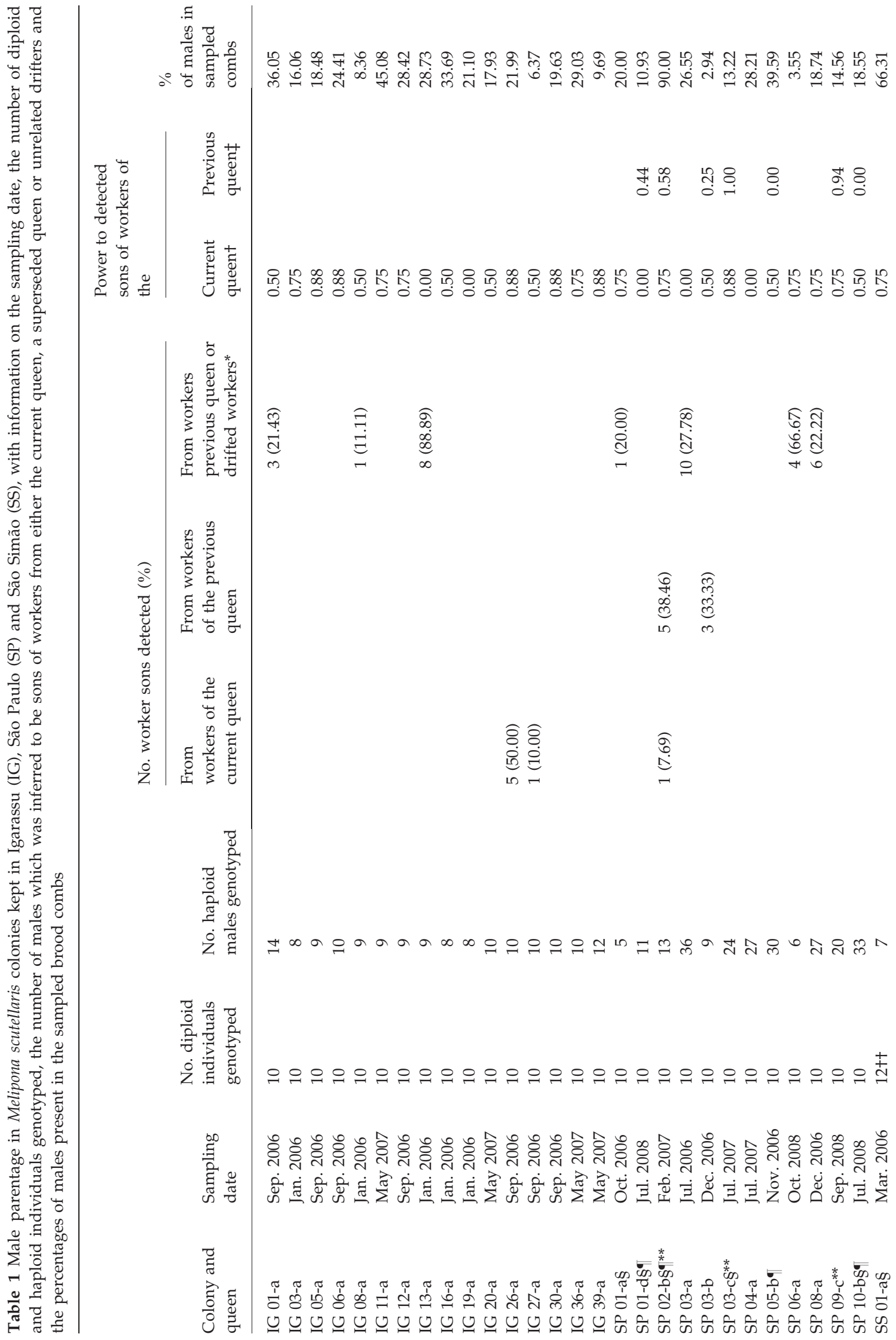


4106 D. A. ALVES ET AL.

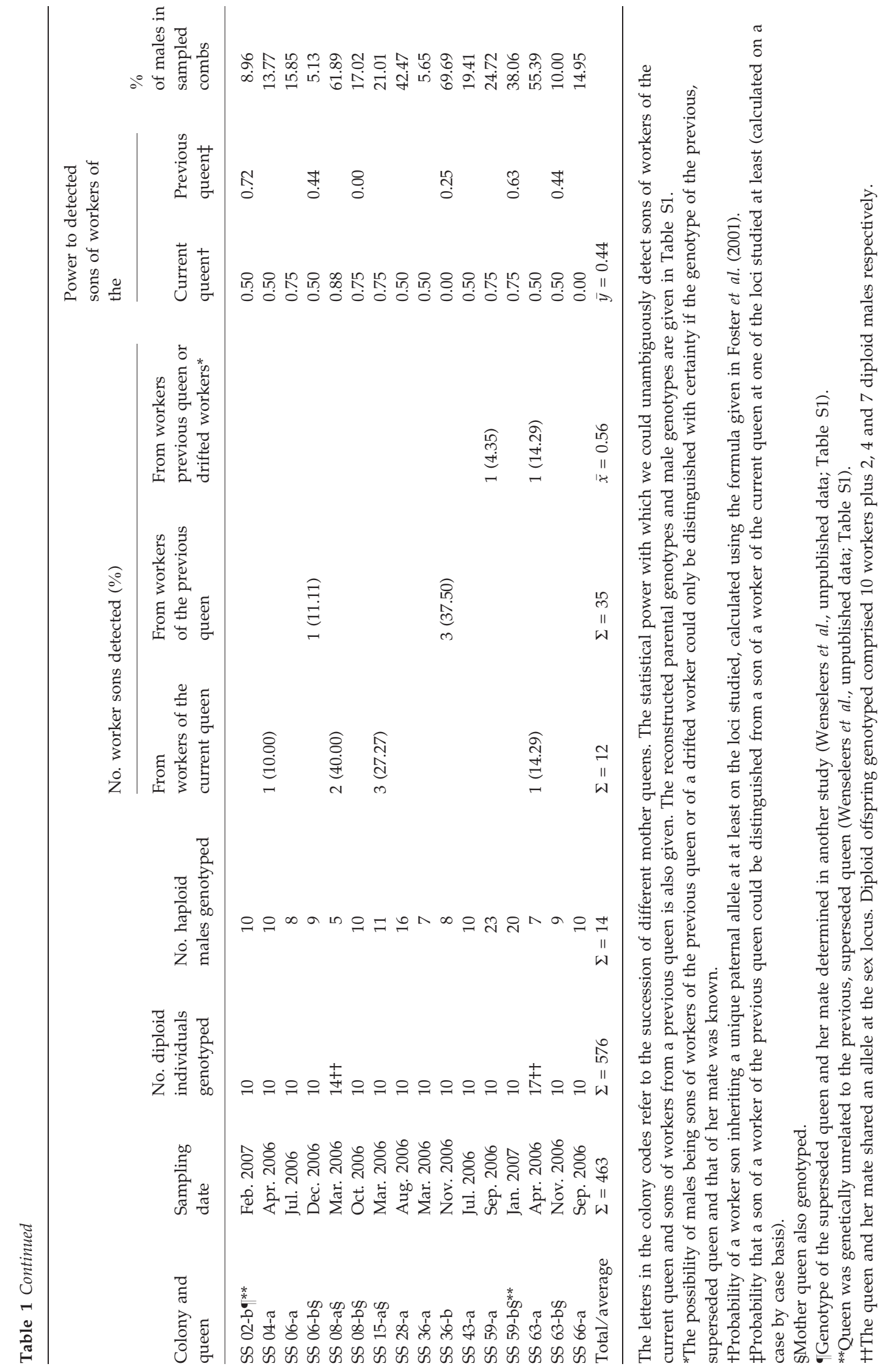


from the genotypes of the diploid brood she produced (worker pupae and occasionally also diploid males, Table 1) (cf. Foster et al. 1999). This was straightforward, given that in all cases, genotypes were consistent with the mother queens being singly mated and with just a single matriline being present. In a few cases, we also had the genotype of the queen herself available, which further facilitated parentage reconstruction (Table S1, Supporting Information). As a null hypothesis, we assumed that males were either sons of the queen or of workers derived from the present queen. These two possibilities could be distinguished if the paternal allele at any one locus was different from the maternal alleles (e.g. parental genotypes of the type $\mathrm{ab} \times \mathrm{c}$ or $\mathrm{aa} \times \mathrm{b}$, but not $\mathrm{ab} \times \mathrm{a}$ ). In that case, a worker's son could be detected if he inherited a unique paternal allele that was not present in the queen (cf. Foster et al. 2001). However, if a male carried an allele not present in either the mother queen or that of its mate, then it was clear that such a male was either the son of a drifted worker or of a worker derived from a superseded queen. The latter two possibilities could be distinguished either by comparison to the known genotypes of workers produced by the previous, superseded queen (Table 1), or by counting the total number of alleles present among such males at each locus in any one colony. The idea is that reproduction by a single superseded matriline of workers should never lead to the presence of more than three alleles, whereas the reproduction by workers that had drifted from multiple colonies might. Estimates of the percentage of males that were sons of workers from the current or previous queen were corrected according to the statistical power with which such males could be detected in our data set given the observed parental genotypes ( $\bar{x}$ and $\bar{y}$, for details see Table 1, cf. Foster et al. 2001). Finally, we also calculated the probability that the son of a drifted worker would by chance be misclassified as the son of the current queen, a son of a worker of the current queen or a son of a worker of the superseded queen, by fortuitously having an identical multilocus genotype. This was carried out using the formula given in Nanork et al. (2005), using the population-specific allele frequencies.

\section{Results}

\section{Allelic diversity and statistical power to detect worker reproduction}

Loci were reasonably polymorphic, with a total of 7,8 and 8 alleles detected (Igarassu: 7, 5, 8; S. Paulo: 6, 8, 7; S. Simão: $4,3,3)$ and mean expected heterozygosities of $79 \%, 71 \%$ and $73 \%$ (Igarassu: $74 \%, 64 \%, 78 \%$; S. Paulo:
77\%, 72\%, 73\%; S. Simão: 51\%, 64\%, 61\%) at loci $T 4-$ 171, Mbi-254 and Mbi-201 respectively. The mean statistical power to detect sons of workers derived from either the current queen or of the previous, superseded queen was $\bar{x}=56 \%$ and $\bar{y}=44 \%$ respectively (Table 1 ), with the latter figure based on 13 colony samples for which we also had the genotypes available of workers produced by the previous, superseded queen (Table 1). The mean probabilities of the son of a drifted worker fortuitously having the same genotype as the son of the current queen, a son of a worker of the current queen or a son of a worker of the superseded queen, were small, $3.81 \%$ (Igarassu: $1.86 \%$; S. Paulo: $2.02 \%$; S. Simão: $6.90 \%$ ), $3.86 \%$ (Igarassu: $3.21 \%$; S. Paulo: $2.65 \%$; S. Simão: $4.76 \%$ ) and $3.57 \%$ (S. Paulo: $2.06 \%$; S. Simão: $4.58 \%)$ respectively. Hence, the probabilities of males being erroneously misclassified were small.

\section{Male parentage}

Out of the 576 males genotyped, $61(10.59 \%)$ could not be assigned to the queen and were therefore definitely workers' sons (Table 1 and Table S1). Only a small percentage of these workers' sons (14 out of 61 ), $22.95 \%$, however, were consistent with being sons of workers of the current queen, and the remainder, 47 out of 61 $(77.05 \%)$, were therefore either derived from drifted workers or from workers produced by an earlier, superseded queen. Restricting ourselves to the subset of 13 colonies for which we had the genotypes available of workers produced by the superseded queen, however, we can see that all the anomalous males (12 out of 12 in four colonies, Table 1) were consistent with being the sons of workers from a superseded queen as opposed to being sons of unrelated, drifted workers (Table S1). In addition, for the remaining colonies where such anomalous male genotypes were found, we never sampled more than three alleles in males at any one locus in any of the colonies, again implying that such males were most probably produced by a single, superseded matriline of workers as opposed to workers that had drifted from several other, unrelated colonies (Table S1). For a few colonies, where only a few anomalous males were found, it remains possible, however, that these were the offspring of drifted workers. Assuming, nevertheless, that the majority of the anomalous males were the offspring of a superseded queen, and correcting our figures for nondetection, we estimate that $77.11 \%$ of the males were the queen's sons, $4.34 \%$ were the sons of the workers derived from the current queen and $18.54 \%$ were the sons of workers derived from a previous, superseded queen. Hence, using these corrected estimates, $81.03 \%$ of all workers' sons were the offspring of workers from superseded queens. 
These figures are surprising given that for the São Paulo population, sons of workers deriving from the superseded queen could still be found in colonies SP 02-b and SP 03-b, despite the fact that these samples were taken 175 and 105 days after the previous queen had died, and that workers in M. scutellaris have a mean life expectancy of only 31 days (Oliveira \& KleinertGiovannini 1991). Even accounting for the fact that some brood laid by the previous queen may have kept enclosing until $\sim 40$ days after her death (the development time from egg to adult in Melipona), and that the sampled brood was probably laid $\sim 25$ days before, we can see that reproductive workers must live a very long time, at least $175-40-25=110$ days, which is 3.5 times as long as that of a normal worker, and in fact not too far off from the life expectancy of queens in this species, 175 days (Wenseleers et al., unpublished data).

There was no significant correlation between the inferred percentage of males that were workers' sons and the percentage of males present in the combs from which the samples were taken (Spearman $R=0.11$, $n=45, P=0.45$ ). This goes against the hypothesis that workers would reproduce mainly during periods in which the queen lays haploid eggs (Chinh et al. 2003; Sommeijer et al. 2003; Velthuis et al. 2005). In fact, in several cases (in colonies IG 08-a, IG 27-a, SP 03-b, SP 06-a and SS 06-b), we found evidence for worker reproduction even at times when fewer than $10 \%$ of the cells contained male pupae (Table 1). So although we concur with Chinh et al. (2003) and Velthuis et al. (2005) that stingless bee queens frequently lay male eggs in distinct batches (during 'male producing periods'), it does not appear to be the case that workers mainly reproduce during such periods, as worker reproduction was found both in periods in which many and in which few males were reared.

\section{Discussion}

Consistent with most previous genetic and behavioural studies on male parentage in stingless bees (reviewed in Hammond \& Keller 2004; Tóth et al. 2004; Velthuis et al. 2005; Wenseleers \& Ratnieks 2006a), our results show that a significant fraction, $22.88 \%$, of the males in Melipona scutellaris are sons of the workers rather than of the queen. This is as expected from inclusive fitness theory, given that single mating in stingless bees collectively favours worker reproduction (Ratnieks 1988; Tóth et al. 2002b, 2004). Surprisingly enough, however, our results also show that $\sim 80 \%$ of the workers' sons had genotypes that were incompatible with them being the sons of workers of the present queen. Based on sampling of colonies over multiple generations, before and after queen supersedure events, and based on the fact that such males from any one colony never had more than three alleles at a given locus, we were able to show that these males were most probably produced by workers that were the offspring of a previous, superseded queen, rather than by workers that had drifted from other colonies. This represents the first demonstration of workers reproductively parasitizing the nextgeneration workforce for their own, selfish benefits.

That such a high percentage of the worker sons were produced by workers derived from a superseded queen is surprising, given that most colonies were sampled many months after the previous queen had died, and that workers in M. scutellaris normally only have a life expectancy of 31 days (Oliveira \& Kleinert-Giovannini 1991; life expectancy of workers in five other Melipona species: 40-51 days, Giannini 1997; Biesmeijer \& Tóth 1998). In fact, in one case, we estimated that reproductive workers had a life expectancy of $\sim 110$ days, which means they outlived the other workers by a factor of 3.5 , and that they had a life expectancy which was almost comparable with that of the queen in this species, 175 days (Wenseleers et al., unpublished data). The long life expectancy of laying workers is probably linked to the fact that reproductive workers usually do not carry out risky or energetically costly tasks, such as foraging, in order for them not to jeopardize their reproductive futures (Franks \& Scovell 1983; Hartmann \& Heinze 2003; Wenseleers et al. 2004b).

The high percentage of males produced by workers derived from superseded queens $(\sim 80 \%)$ was also surprising given that for colonies sampled at random points in time, such workers usually present only a very small fraction of the workforce. For example, the percentage of workers that had either drifted from other colonies or were descendants of a superseded queen was estimated at 3\% across a sample of 12 species of stingless bees (Peters et al. 1999; excluding the facultatively polygyne Melipona bicolor), $10 \%$ in Melipona beecheii (Paxton et al. 1999a) and between 21\% and 36\% across three species of Scaptotrigona (Paxton et al. 1999a, 2003; Palmer et al. 2002). Overall, this probably means that, on a per capita basis, the workers from superseded queens specialize in reproduction. Partly, this may be due to the fact that during the brief period of queenlessness following the death of the queen and preceding the establishment of a new laying queen, workers increase their rate of ovary activation as well as their egg-laying rate (Ferreira et al. 1989; Lacerda \& Zucchi 1999; Kleinert 2005; Velthuis et al. 2005), and that this may give these workers a 'head start' relative to the workers produced later by the newly mother queen. However, the greater reproductive rate of workers derived from a superseded queen is also consistent with kin selection theory, given that it pays workers more 
from exploiting the colony if costs are carried by less related individuals (Hamilton 1964; Wenseleers et al. 2004a, b; Ratnieks et al. 2006; Wenseleers \& Ratnieks 2006b). In stingless bees, worker reproduction is probably to be costly, first because workers might carry out less work (but see Cepeda (2006) who shows that reproductive workers in $M$. bicolor do engage in some brood care), and second because the exclusively male eggs laid by workers will end up replacing some of the female, worker-destined eggs laid by the queen (Ratnieks \& Reeve 1992; Tóth et al. 2004). Hence, worker reproduction in stingless bees will inevitably be traded off against worker production, and come at a cost to future colony productivity (Ratnieks \& Reeve 1992; Tóth et al. 2004). From the perspective of workers from a previous queen, however, this cost will in inclusive fitness terms be lower as it will be carried by more distantly related individuals (nephews and nieces, $r=0.375$, as opposed to sisters, $r=0.75$ ), thereby causing them to be selected to exploit the colony more. These results are the first explicit demonstration that conflict over male parentage in insect societies is not just played out between the queen and workers and between the workers of one generation, but that the conflict may also spill over from one worker generation to the next. Future work will be required to test if such intergenerational worker reproduction conflict occurs more widely in other perennial insect societies.

\section{Acknowledgements}

We thank FAPESP (05/58093-8 to DAA; 04/15801-0 to VLIF and PSSF), CNPq (480957/2004-5 to VLIF; $151947 / 2007-4$ to TMF) and the FWO-Flanders (to TW and JB) for financial support and Madeleine Beekman and Ben Oldroyd for constructive comments. We are especially thankful to Francisco and Selma Carvalho for helping us to collect some of the samples. Work was carried out under permit numbers 139311, 08BR001591/DF and 08BR002483/DF from the Brazilian Ministry of Environment.

\section{References}

Alves RMO, Carvalho CAL, Souza BA (2005) Ninhos de Melipona scutellaris L. em coqueiros na região do litoral Norte e metropolitana no Estado da Bahia. Mensagem Doce, 83, 3-5.

Beekman M, Oldroyd BP (2008) When workers disunite: intraspecific parasitism by eusocial bees. Annual Review of Entomology, 53, 19-37.

Beekman M, Ratnieks FLW (2003) Power over reproduction in social Hymenoptera. Philosophical Transactions of the Royal Society of London (Series B), 358, 1741-1753.

Biesmeijer JC, Tóth E (1998) Individual foraging, activity level and longevity in the stingless bee Melipona beecheii in Costa Rica (Hymenoptera, Apidae, Meliponinae). Insectes Sociaux, 45, 427-443.
Bonckaert W, Vuerinckx K, Billen J, Hammond RL, Keller L, Wenseleers T (2008) Worker policing in the German wasp Vespula germanica. Behavioral Ecology, 19, 272-278.

Bourke AFG (1988) Worker reproduction in the higher eusocial Hymenoptera. Quarterly Review of Biology, 63, 291-311.

Camargo JMF, Pedro SRM (2007) Meliponini Lepeletier, 1836. In: Catalogue of Bees (Hymenoptera, Apoidea) in the Neotropical Region (eds Moure JS, Urban D, Melo GAR), pp. 272-578. Sociedade Brasileira de Entomologia, Curitiba.

Castro MS (2002) Bee fauna of some tropical and exotic fruits: potencial pollinators and their conservation. In: Pollinating Bees-The Conservation Link between Agriculture and Nature (eds Kevan P, Imperatriz-Fonseca VL), pp. 275-288. Ministry of Environment, Brasília.

Cepeda OI (2006) Division of labor during brood production in stingless bees with special reference to individual participation. Apidologie, 37, 175-190.

Châline N, Ratnieks FLW, Raine NE, Badcock NS, Burke T (2004) Non-lethal sampling of honey bee, Apis mellifera, DNA using wing tips. Apidologie, 35, 311-318.

Chapman NC, Nanork P, Gloag R, Wattanachaiyingcharoen W, Beekman M, Oldroyd BP (2009) Queenless colonies of the Asian red dwarf honey bee (Apis florea) are infiltrated by workers from other queenless colonies. Behavioral Ecology, 20, 817-820. doi: 10.1093/beheco/arp065.

Chinh TX, Grob GBJ, Meeuwsen FJAJ, Sommeijer MJ (2003) Patterns of male production in the stingless bee Melipona favosa (Apidae, Meliponini). Apidologie, 34, 161-170.

Cole BJ (1986) The social behavior of Leptothorax allardycei (Hymenoptera, Formicidae): time budgets and the evolution of worker reproduction. Behavioral Ecology and Sociobiology, 18, 165-173.

Contel EPB, Kerr WE (1976) Origin of males in Melipona subnitida estimated from data of an isozymic polymorphic system. Genetica, 46, 271-279.

Cortopassi-Laurino M, Imperatriz-Fonseca VL, Roubik DW et al. (2006) Global meliponiculture: challenges and opportunities. Apidologie, 37, 275-292.

Drumond PM, Oldroyd BP, Osborne K (2000) Worker reproduction in Austroplebeia australis Friese (Hymenoptera, Apidae, Meliponini). Insectes Sociaux, 47, 333-336.

Ferreira LM, Albuquerque CMRD, Hadj-Idris AEQ (1989) Bionomic aspects in Melipona scutellaris (Hymenoptera, Apidae, Meliponinae): egg laying by workers and food provisioning. Revista Brasileira de Entomologia, 33, 217-224.

Foster KR, Seppa P, Ratnieks FLW, Thorén PA (1999) Low paternity in the hornet Vespa crabro indicates that multiple mating by queens is derived in vespine wasps. Behavioral Ecology and Sociobiology, 46, 252-257.

Foster KR, Ratnieks FLW, Gyllenstrand N, Thorén PA (2001) Colony kin structure and male production in Dolichovespula wasps. Molecular Ecology, 10, 1003-1010.

Franks NR, Scovell E (1983) Dominance and reproductive success among slave-making worker ants. Nature, 304, 724-725.

Giannini KM (1997) Labor division in Melipona compressipes fasciculata Smith (Hymenoptera: Apidae: Meliponinae). Anais da Sociedade Entomológica do Brasil, 26, 153-162.

Gloag RS, Beekman M, Heard TA, Oldroyd BP (2007) No worker reproduction in the Australian stingless bee Trigona carbonaria Smith (Hymenoptera, Apidae). Insectes Sociaux, 54, 412-417. 
Hamilton WD (1964) The genetical evolution of social behaviour. I \& II. Journal of Theoretical Biology, 7, 1-52.

Hammond RL, Keller L (2004) Conflict over male parentage in social insects. PLoS Biology, 2, 1-11.

Hartmann A, Heinze J (2003) Lay eggs, live longer: division of labor and life span in a clonal ant species. Evolution, 57, 2424-2429.

Heard TA (1999) The role of stingless bees in crop pollination. Annual Review of Entomology, 44, 183-206.

Hillesheim E, Koeniger N, Moritz RFA (1989) Colony performance in honeybees (Apis mellifera capensis Esch) depends on the proportion of subordinate and dominant workers. Behavioral Ecology and Sociobiology, 24, 291-296.

Kleinert A (2005) Colony strength and queen replacement in Melipona marginata (Apidae: Meliponini). Brazilian Journal of Biology, 65, 469-476.

Koedam D, Contrera FAL, Fidalgo AO, Imperatriz-Fonseca VL (2005) How queen and workers share in male production in the stingless bee Melipona subnitida Ducke (Apidae, Meliponini). Insectes Sociaux, 52, 114-121.

Lacerda LD, Zucchi R (1999) Behavioral alterations and related aspects in queenless colonies of Geotrigona mombuca (Hymenoptera, Apidae, Meliponinae). Sociobiology, 33, 277288.

Lopez-Vaamonde C, Koning JW, Brown RM, Jordan WC, Bourke AFG (2004) Social parasitism by male-producing reproductive workers in a eusocial insect. Nature, 430, 557-560.

Nanork P, Paar J, Chapman NC, Wongsiri S, Oldroyd BP (2005) Asian honeybees parasitize the future dead. Nature, $437,829$.

Nanork P, Chapman NC, Wongsiri S et al. (2007) Social parasitism by workers in queenless and queenright Apis cerana colonies. Molecular Ecology, 16, 1107-1114.

Ohtsuki H, Tsuji K (2009) Adaptive reproduction schedule as a cause of worker policing in social Hymenoptera: a dynamic game analysis. The American Naturalist, 173, 747-758.

Oliveira HH, Kleinert-Giovannini A (1991) Influência da sazonalidade na divisão de trabalho entre operárias de Melipona scutellaris Latreille (Apidae, Meliponinae). Ciência $\mathcal{E}$ Cultura, 43, 758.

Oster GF, Wilson EO (1978) Caste and Ecology in the Social Insects. Princeton University Press, Princeton, NJ.

Palmer KA, Oldroyd BP, Quezada-Euán JJG, Paxton RJ, MayItza WDJ (2002) Paternity frequency and maternity of males in some stingless bee species. Molecular Ecology, 11, 21072113.

Paxton RJ, Weissschuh N, Engels W, Hartfelder K, QuezadaEuan JJG (1999a) Not only single mating in stingless bees. Naturwissenschaften, 86, 143-146.

Paxton RJ, Weissschuh N, Quezada-Euan JJG (1999b) Characterization of dinucleotide microsatellite loci for stingless bees. Molecular Ecology, 8, 690-692.

Paxton RJ, Bego LR, Shah MM, Mateus S (2003) Low mating frequency of queens in the stingless bee Scaptotrigona postica and worker maternity of males. Behavioral Ecology and Sociobiology, 53, 174-181.

Peters JM, Queller DC, Imperatriz-Fonseca VL, Strassmann JE (1998) Microsatellite loci for stingless bees. Molecular Ecology, 7, 784-787.

Peters JM, Queller DC, Imperatriz-Fonseca VL, Roubik DW, Strassmann JE (1999) Mate number, kin selection and social conflicts in stingless bees and honeybees. Proceedings of the Royal Society of London. Series B: Biological Sciences, 266, 379.

Ratnieks FLW (1988) Reproductive harmony via mutual policing by workers in eusocial Hymenoptera. The American Naturalist, 132, 217-236.

Ratnieks FLW, Reeve HK (1992) Conflict in single-queen hymenopteran societies: the structure of conflict and processes that reduce conflict in advanced eusocial species. Journal of Theoretical Biology, 158, 33-65.

Ratnieks FLW, Visscher PK (1989) Worker policing in the honeybee. Nature, 342, 796-797.

Ratnieks FLW, Wenseleers T (2008) Altruism in insect societies and beyond: voluntary or enforced? Trends in Ecology $\mathcal{E}$ Evolution, 23, 45-52.

Ratnieks FLW, Foster KR, Wenseleers T (2006) Conflict resolution in insect societies. Annual Review of Entomology, 51, 581-608.

Sommeijer MJ, Chinh TX, Meeuwsen FJAJ (1999) Behavioural data on the production of males by workers in the stingless bee Melipona favosa (Apidae, Meliponinae). Insectes Sociaux, 46, 92-93.

Sommeijer MJ, de Bruijn LLM, Meeuwsen FJAM, Martens EP (2003) Natural patterns of caste and sex allocation in the stingless bees Melipona favosa and M. trinitatis related to worker behaviour. Insectes Sociaux, 50, 38-44.

Tóth E, Queller DC, Imperatriz-Fonseca VL, Strassmann JE (2002a) Genetic and behavioral conflict over male production between workers and queens in the stingless bee Paratrigona subnuda. Behavioral Ecology and Sociobiology, 53, 1-8.

Tóth E, Strassmann JE, Nogueira-Neto P, Imperatriz-Fonseca VL, Queller DC (2002b) Male production in stingless bees: variable outcomes of queen-worker conflict. Molecular Ecology, 11, 2661-2667.

Tóth E, Strassmann JE, Imperatriz-Fonseca VL, Queller DC (2003) Queens, not workers, produce the males in the stingless bee Schwarziana quadripunctata quadripunctata. Animal Behaviour, 66, 359-368.

Tóth E, Queller DC, Dollin A, Strassmann JE (2004) Conflict over male parentage in stingless bees. Insectes Sociaux, 51, $1-11$.

Trivers RL, Hare H (1976) Haplodiploidy and the evolution of the social insects. Science, 191, 249-263.

Velthuis HHW, Koedam D, Imperatriz-Fonseca VL (2005) The males of Melipona and other stingless bees, and their mothers. Apidologie, 36, 169-185.

Wenseleers T, Ratnieks FLW (2006a) Comparative analysis of worker reproduction and policing in eusocial Hymenoptera supports relatedness theory. The American Naturalist, 168 E163-E179.

Wenseleers T, Ratnieks FLW (2006b) Enforced altruism in insect societies. Nature, 444, 50.

Wenseleers T, Hart AG, Ratnieks FLW (2004a) When resistance is useless: policing and the evolution of reproductive acquiescence in insect societies. The American Naturalist, 164, E154-E167.

Wenseleers T, Helanterä H, Hart A, Ratnieks FLW (2004b) Worker reproduction and policing in insect societies: an ESS analysis. Journal of Evolutionary Biology, 17, 1035-1047.

Wenseleers T, Tofilski A, Ratnieks FLW (2005a) Queen and worker policing in the tree wasp Dolichovespula sylvestris. Behavioral Ecology and Sociobiology, 58, 80-86. 
Wenseleers T, Badcock NS, Erven K et al. (2005b) A test of worker policing theory in an advanced eusocial wasp. Vespula rufa. Evolution, 59, 1306-1314.

This work forms part of D.A.A.'s PhD research on the ecological and genetic basis of social behaviour in stingless bees, and the conservation biology and viability of small populations. V.L.I.F. is interested in the behaviour, evolution and conservation of stingless bees and is the head of the bee laboratory at the University of São Paulo. T.M.F. is interested in evaluating the genetic and morphological biodiversity in bee populations for their conservation and uses honey bees, stingless bees and orchid bees as his main model systems. P.S.S.F. works on the ecology and evolution of stingless bees. P.N.N. works on the ecology and breeding of stingless bees, with emphasis on their conservation, behaviour and sustainable use. J.B. is the leader of the Laboratory of Entomology at the University of Leuven and has a longstanding interest in the social organization of insect societies. T.W. is an evolutionary biologist interested in the origin and evolution of social behaviour, and uses wasps, stingless bees and honey bees as his main model systems.

\section{Supporting information}

Additional Supporting Information may be found in the online version of this article:

Table S1 Reconstructed parental genotypes and male genotypes observed in Melipona scutellaris colonies kept at Igarassu (IG), São Paulo (SP) and São Simão (SS), with information on whether the males were inferred to be sons of workers of the current queen (WSC), sons of workers of the previous queen (WSP) or sons of either workers of the previous queen or of drifted workers (WSP/D)

Please note: Wiley-Blackwell is not responsible for the content or functionality of any supporting information supplied by the authors. Any queries (other than missing material) should be directed to the corresponding author for the article. 